Journal of Animal and Veterinary Advances 10 (12): 1603-1606, 2011

ISSN: $1680-5593$

(C) Medwell Journals, 2011

\title{
Olanzapine Administration Shortened the Laying Interval in Pigeon (Columba livia)
}

\author{
Min Zhang, X.T. Zou, Jin-Guo Liu and Y.M. Wang \\ Key Laboratory of Molecular Animal Nutrition, Ministry of Education, \\ College of Animal Science, Zhejiang University, 310029 Hang Zhou, China
}

\begin{abstract}
About 120 pairs of American king pigeon were used to investigate the effect of olanzapine on laying interval. Olanzapine was added to the basal diet of 720 days old pigeon breeders at the level of $0,0.5,0.75$ and $1.25 \mathrm{mg} \mathrm{kg}^{-1}$, respectively. During 60 days of treatment, laying interval of 0.75 and $1.25 \%$ group decreased significantly by 37.46 and $29.83 \%$ ( $<<0.05$ ), respectively. This change was accompanied by significantly elevated plasma FSH and progesterone levels whereas declined PRL levels and diminished Prolactin Receptor (PRLR) mRNA expression in liver of olanzapine-treated pigeons. The results provided evidence that olanzapine shorten the laying intervals accompanying with changes in the secretion of hormones and expression of PRLR gene.
\end{abstract}

Key words: American king pigeon, hormone levels, laying interval, Olanzapine, prolactin receptor mRNA expression, China

\section{INTRODUCTION}

Aves incubating by instinct however, this behavior bring a long interval of egg laying. Prolactin (PRL), a polypeptide hormone secreted mainly by the pituitary and to a lesser extent by peripheral tissues, affects more physiological processes than all other pituitary hormones combined since it is involved in above three hundred separate functions in vertebrates. It's reported that in birds prolactin plays a role in the maintenance of incubation behavior this decrease could have caused a decrease in the drive to incubate. The initial step of PRL action is the binding to a specific membrane receptor, the PRLR which belongs to the class 1 cytokine receptor superfamily and the secretion of PRL is modulated by the pituitary hormones such as Vasoactive Intestinal Peptide (VIP), 5HT, dopamine and so on. It has been proved that $5 \mathrm{HT}$ stimulate and dopamine both stimulate and diminish (mainly diminish) PRL secretion in Turkey (El-Halawania et al., 1988; Wong et al., 1992).

Incubation as a kind of neuroendocrine modulated behavior could be affected by antipsychotics. Olanzapine is one of novel atypical antipsychotics with affinity for a number of neurotransmitter receptors which has a significant in vitro inhibitor activity on dopamine $\mathrm{D}_{1}, \mathrm{D}_{2}$, $\mathrm{D}_{4}$, serotonin $5 \mathrm{HT}_{2 \mathrm{~A}}, 5 \mathrm{HT}_{2 \mathrm{c}}$, histamine $\mathrm{H}_{1}, \mathrm{a}_{1}$-adrenergic and muscarinic receptors (Tollefson et al., 1997). The research was to find the effect of olanzapine administration on incubation and endocrine.

\section{MATERIALS AND METHODS}

Animals: American king pigeon (Columba livia) is first breed in America and then introduced to China characterized by big body size and high reproductions. In the experiment, 120 pairs of American king pigeon breeders ( 720 days old) during post-peak period of egg lay were selected and randomly allocated to one control and three olanzapine-treated groups with olanzapine supplemented to the basal diet at the level of $0,0.5,0.75$ and $1.25 \mathrm{mg} \mathrm{kg}^{-1}$, respectively for a period of 60 days. Pigeons were kept in the Xing Liang Pigeon Breeding Company of Wen Zhou city, Zhejiang province, China, following the feeding and housing standards of the breed. Pigeons were given free access to water and food under natural lighting. At the end of the experiment, six pigeons from each group were randomly selected and sacrificed for blood and liver. Sera were stored at $-20^{\circ} \mathrm{C}$ until biochemical parameter and hormone assay. Livers were immediately frozen in liquid nitrogen and stored at $-80^{\circ} \mathrm{C}$ until RNA isolation.

Diets: The diets for pigeons were formulated according to their nutritional requirements as shown in Table 1.

Materials: Olanzapine was bought from Hua Dong Medicine Company with a purity of $99.9 \%$. The Avian Myeloblastosis Virus (AMV) reverse transcriptase, Taq DNA polymerase and other related reagents were products of Sheng-gong (Shanghai, China). 
Table 1: Nutrients and compositions of experimental diet

\begin{tabular}{lclr}
\hline Ingredient & Percentage & Nutrient level & Values \\
\hline Corn & 48.0 & $\mathrm{DE}\left(\mathrm{MJ} \mathrm{kg}^{-1}\right)$ & 11.47 \\
Wheat & 13.0 & $\mathrm{CP}(\%)$ & 16.89 \\
Horsebean & 19.0 & $\mathrm{Ca}(\%)$ & 0.87 \\
Soybean meal & 10.0 & $\mathrm{P}(\%)$ & 0.75 \\
Wheat bran & 5.0 & Met (\%) & 0.24 \\
Bone meal & 2.5 & Lys (\%) & 0.83 \\
\hline
\end{tabular}

Radioimmunoassay for serum hormone levels: The serum concentrations of PRL, FSH, LH, progesterone and E2 were measured with Radioimmunoassay (RIA) using PACKARD D5002- $\gamma$ arithmometer (America).

RNA extraction: Total RNA was extracted from the tissue samples with Trizol methods and the RNA concentration was then quantified by measuring the absorbance at $260 \mathrm{~nm}$ in a photometer (Eppendorf Biophotometer). Ratios of absorption $(260 / 280 \mathrm{~nm})$ of all preparations were between 1.8 and 2.0 .

Reverse Transcription (RT) and Polymerase Chain Reaction (PCR): About $2 \mathrm{mg}$ of total RNA was reverse transcribed by incubation at $42^{\circ} \mathrm{C}$ for $1 \mathrm{~h}$ in a $20 \mu \mathrm{L}$ mixture consisting of $10 \mathrm{U}$ avian myeloblastosis virus reverse transcriptase, $20 \mathrm{U}$ RNase inhibitor, 2.4 AM Oligo (dT10) primer, $1 \mathrm{mM}$ each dNTP, $50 \mathrm{mM}$ Tris- $\mathrm{HCl}$ (pH 8.3), $10 \mathrm{mM}$ $\mathrm{MgCl}_{2}, \mathrm{RNA}$ samples were denatured at $80^{\circ} \mathrm{C}$ for $5 \mathrm{~min}$ and placed on ice for $5 \mathrm{~min}$ together with the Oligo (dT10) primer and dNTP before Reverse Transcription (RT). The $\mathrm{RT}$ reaction was terminated by heating at $95^{\circ} \mathrm{C}$ for $5 \mathrm{~min}$ and quickly cooled on ice.

About $2 \mu \mathrm{L}$ of RT reaction mix was used for PCR in a final volume of $50 \mu \mathrm{L}$ containing $0.4 \mu \mathrm{L}$ Taq DNA polymerase, $5 \mu \mathrm{L} 10 \times$ PCR buffer, $1 \mu \mathrm{L}$ each $\mathrm{dNTP}, 1.5 \mu \mathrm{L}$ $\mathrm{MgCl}_{2}, 1 \mu \mathrm{L}$ specific primers for target genes. PCR conditions were: $94^{\circ} \mathrm{C} 2 \mathrm{~min}, 55^{\circ} \mathrm{C} 45 \mathrm{sec}$ and $72^{\circ} \mathrm{C} 1 \mathrm{~min}$. The PCR primers for PRLR was designed using Primer. Premier 5.0 and were synthesized by Sheng-Gong (Shanghai, China). The nucleotide sequences of primers were:

PRLR F: 5' ACTGGTCAATCATACCCTGGAA 3' PRLR R: 5' ACACAACGGACCTGAACAACA 3' $\beta$-actin F: 5' TGATATTGCTGCGCTCGTT 3' $\beta$-actin R: 5' CTCATTGTAGAAAGTGTGGTGC 3'

Quantitation of PCR products: An aliquot $(5 \mu \mathrm{L})$ of PCR products was analyzed by electrophoresis on $2 \%$ agarose gels. The gel was stained with ethidium bromide and photographed with a digital camera (Immage master VDS, USA). The net intensities of individual bands were measured using Immage Master VDS Software. The ratios of net intensities of target genes to $\beta$-actin were used to represent the relative levels of target genes expression. The average level of three repeats was used for statistical analysis. All data were expressed as Mean $\pm \mathrm{SD}$.

Statistical analysis: All the data were subjected to ANOVA using SPSS (SPSS 11.5). Contrasts between means were evaluated by Tukey's test at significance level of $5 \%$. All data were expressed as Mean $\pm \mathrm{SD}$.

\section{RESULTS AND DISCUSSION}

Serum hormone levels: Compared to the control, the level of serum hormone as shown in Table 2, 1.25, 0.75 and $0.25 \mathrm{mg} \mathrm{kg}^{-1}$ group PRL significantly decreased by 34.5321 .90 and $9.71 \%$, respectively. Whereas there were significant elevation in FSH and progestin levels, increased by $28.5,24.0,15.2,42.0,33.7$ and $22.8 \%$, respectively. The data disclosed an increase of $\mathrm{LH}$ in trialed groups but the differences were not significant.

Relative abundance of PRLR mRNA: Addition of olanzapine exerted negative influences in mRNA expression of PRLR (Fig. 1). Compared to control group, $1.25 \mathrm{mg} \mathrm{kg}^{-1}$ olanzapine significantly decreased the relative mRNA expression of PRLR by $14.3 \%(\mathrm{p}<0.05)$.

Laying interval: Addition of olanzapine shortened the brooding duration (Fig. 2). Compared to the control, laying interval of 0.75 and $1.25 \%$ group were significantly shortened by 37.46 and $29.83 \%$ ( $<<0.05$ ), respectively. And the interval declined as the addition of olanzapine increased.

Although, many neurotransmitters might play a role in prolactin regulation, modulation by dopaminergic mechanisms is probably the most important neurotransmitter system involved. Blockade of dopamine receptors by antipsychotics in the tuberoinfundibular tract releases the inhibition of prolactin storage cells, resulting in elevation of prolactin levels. In contrast to dopamine, serotonin acts to stimulate prolactin release by an inhibiting effect on the dopaminergic influence on the tuberoinfundibular tract. A consequence of this mechanism is that serotonergic influences can modulate (dopamine-mediated) prolactin release but serotonin can only show this effect as long as the dopaminergic influence is present. It's been proved that all antipsychotics are dopamine blockers while some antipsychotics for example, olanzapine are also serotonin blockers (Knegtering et al., 2003). There were plenty research on serum prolactin level of schizophrenia (men and women, human and rat) and most of the investigations showed that olanzapine's effect on 
Table 2: Effects of olanzapine on serum hormone levels

\begin{tabular}{|c|c|c|c|c|}
\hline Hormones & Control & Ola $0.25 \mathrm{mg} \mathrm{kg}^{-1}$ & Ola $0.75 \mathrm{mg} \mathrm{kg}^{-1}$ & Ola1.25 $\mathrm{mg} \mathrm{k}^{-1}$ \\
\hline $\operatorname{PRL}\left(\mu \mathrm{IU} \mathrm{mL}^{-1}\right)$ & $328.16 \pm 30.12^{a}$ & $296.31 \pm 25.66^{b}$ & $256.32 \pm 21.65^{\mathrm{c}}$ & $214.86 \pm 16.78^{c}$ \\
\hline $\mathrm{FSH}\left(\mathrm{mIU} \mathrm{mL}^{-1}\right)$ & $56.60 \pm 10.11^{\mathrm{a}}$ & $65.21 \pm 16.02^{b}$ & $70.16 \pm 20.56^{b c}$ & $72.75 \pm 16.35^{c}$ \\
\hline $\mathrm{LH}\left(\mathrm{mIU} \mathrm{mL}^{-1}\right)$ & $81.25 \pm 20.31$ & $91.11 \pm 30.16$ & $99.56 \pm 25.36$ & $100.42 \pm 26.76$ \\
\hline $\mathrm{E}_{2}\left(\mathrm{pg} \mathrm{mL} \mathrm{L}^{-1}\right)$ & $334.12 \pm 15.03$ & $360.35 \pm 10.66$ & $380.51 \pm 20.23$ & $387.66 \pm 12.62$ \\
\hline Progesterone (ng mL ${ }^{-1}$ ) & $1.93 \pm 0.120^{a}$ & $2.37 \pm 0.130^{b}$ & $2.58 \pm 0.210^{c}$ & $2.74 \pm 0.098^{\mathrm{c}}$ \\
\hline
\end{tabular}

Different letters within the same line indicate significant differences $(p<0.05)$
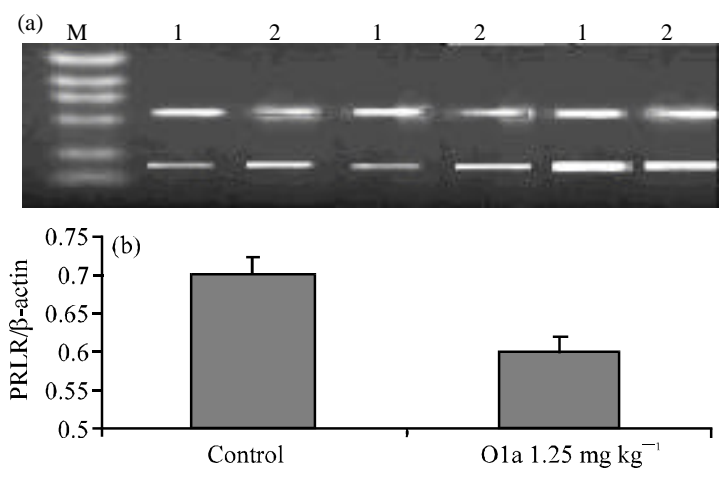

Fig. 1: Effect of olanzapine on the relative abundance of PRLR mRNA in liver of pigeons. (a) Representative electrophoresis photo of RT-PCR products for PRLR mRNA and $\beta$-actin mRNA. M: DNA molecular weight marker. 1: control, 2: olanzapine $1.25 \mathrm{mg} \mathrm{kg}^{-1}$ (b) Results of statistical analysis for PRLR mRNA levels expressed as arbitrary units relative to $\beta$-actin mRNA. Values are means \pm SD

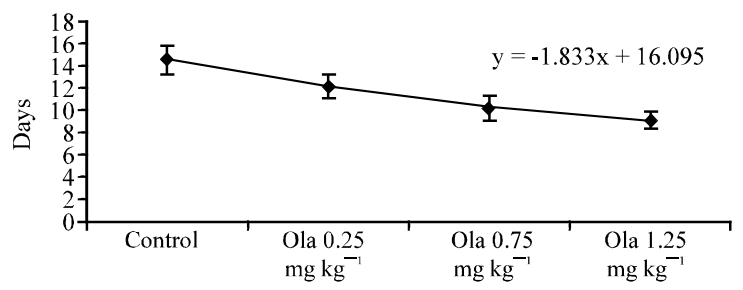

Fig. 2: Effect of olanzapine on laying interval

prolactin were not significant (Meaney and O'Keane, 2002). In the studies, we found that the administration of olanzapine can significantly reduce the serum prolactin levels; it's probably because olanzapine played more serotonin blocker than dopamine blocker functions in these healthy birds. Though there was no clear mechanism of relationship between FSH and olanzapine, the secretion of FSH probably modulated by dopamine and serotonin too. The elevation of progestin level was coinciding with the trials conducted on rats (Frye and Seliga, 2002, 2003). It's been proved that the expression of PRLR could induce PRL expression and modulates PRL inducible signal transmitting (Marone et al., 1997; Vleck et al., 2000). According to the studies, olanzapine lowered the binding rates of PRL and PRLR by decreasing the PRLR mRNA expression and PRL level. This result implicated that hypothalamic DA (dopamine) and 5-HT (5-hydroxytryptamine) activities were the vital causes of development and maintenance of broodiness and pituitary PRL secretion.

\section{CONCLUSION}

In the study, these results inferred that the potential mechanism of olanzapine affecting laying intervals was probably through increasing $\mathrm{FSH}$ and progesterone levels, decreasing PRL levels and weakening the level of PRLR mRNA expression.

\section{ACKNOWLEDGEMENTS}

This research was supported by the National Natural Science Foundation of China (No. 30871803) and the Major Special Program for International Cooperation of Zhejiang province (No. 2008C14074).

\section{REFERENCES}

El-Halawania, M.E., O.M. Youngrenb, J.L. Silsbya and R.E. Phillipsb, 1988. Involvement of serotonin in prolactin release induced by electrical stimulation of the hypothalamus of the Turkey (Meleagris gallopavo). Gen. Comp. Endocrinol., 72: 323-328.

Frye, C. and A. Seliga, 2002. Olanzapine and progesterone have dose-dependent and additive effects to enhance lordosis and progestin concentrations of rats. Physiol. Behav., 76: 151-158.

Frye, C.A. and A.M. Seliga, 2003. Olanzapines effects to reduce fear and anxiety and enhance social interactions coincide with increased progestin concentrations of ovariectomized rats. Psychoneuroendocrinology, 28: 657-673.

Knegtering, H., A.E.G.M. van der Moolen, S. Castelein, H. Kluiter and R.J. van den Bosch, 2003. What are the effects of antipsychotics on sexual dysfunctions and endocrine functioning. Psychoneuroendocrinology, 28: 109-123.

Marone, M., G. Scambia, C. Giannitelli, G. Ferrandina and V. Masciullo et al., 1997. Cyclin E and cdk2 alterations in ovarian cancer: Amplification and over expression. Int. J. Cancer, 74: 390-395. 
Meaney, A.M. and V. O'Keane, 2002. Prolactin and schizophrenia: Clinical consequences of hyperprolactinaemia. Life Sci., 71: 979-992.

Tollefson, G.D., C.M. Jr. Beasley, P.V. Tran, J.S. Street and J.A. Krueger et al., 1997. Olanzapine versus haloperidol in the treatment of schizophrenia and schizoaffective and schizophreniform disorders: Results of an international collaborative trial. Am. J. Psychiatry, 154: 457-465.
Vleck, C.M., L.L. Ross, D. Vleck and T.L. Bucher, 2000. Prolactin and parental behavior in Adelie penguins: Effects of absence from nest, incubation length and nest failure. Horm. Behav., 38: 149-158.

Wong, E.A., J.L. Silsby, S. Ishii, M.E. El-Halawani, 1992. Pituitary luteinizing hormone and prolactin messenger ribonucleic acid levels are inversely related in laying and incubating Turkey hens. Biol. Reprod., 47: 598-602. 